\title{
Nieznane groby średniowiecznych duchownych z kolegiaty pw. św. św. Piotra i Pawła w Kruszwicy
}

Zarys treści: Autorka omawia obiekty datowane na XII w., odnalezione w grobach w kościele kolegiackim w Kruszwicy: kielich z pateną, fragmenty taśmy jedwabnej z wyhaftowanym napisem, i jedwabną, haftowaną stułę. Zabytki te wskazują, że pogrzebane z nimi osoby zajmowały wysoką pozycję w hierarchii kościelnej. Zdaniem autorki pochówki tych osób potwierdzają opinię, zgodnie z którą Kruszwica była w pierwszej połowie XII w. siedzibą biskupią, a omawiany kościół miejscem pochówków prałatów.

Abstract: The author discusses objects dated as twelfth-century and discovered in tombs in the collegiate church in Kruszwica: a chalice with a paten, fragments of a silk fabric with an embroidered inscription, and an embroidered silk stole. The monuments in question indicate that the persons buried together with them occupied a high position in the Church hierarchy. In the opinion of the author these burials confirm a view maintaining that in the first half of the twelfth century Kruszwica was the seat of a bishopric and the discussed church - the burial site of prelates.

Słowa kluczowe: kolegiata, grób, szaty pontyfikalne, stuła, mitra, kielich, patena, biskup, biskupstwo kruszwickie. Keywords: collegiate church, grave, pontifical vestments, stole, chalice, paten, bishop, Kruszwica bischopric.

W latach 1960-1961 w ramach badań nad Początkami Państwa Polskiego przeprowadzono badania wykopaliskowe we wnętrzu kościoła kolegiackiego pod wezwaniem świętych Piotra i Pawła w Kruszwicy. Badaniami kierowała ś.p. mgr Ewa Springer. Wyniki prac nie zostały dotychczas w pełni opublikowane'.

Wśród wyeksplorowanych wówczas we wnętrzu budowli 326 grobów, na szczególną uwagę zasługują dwa, które zawierały szczątki jedwabnych haftowanych szat, najprawdopodobniej liturgicznych. Są to grób oznaczony numerem 24/II położony w północnym skrzydle transeptu i grób nr 70/VII, znajdujący się w nawie głównej na wysokości jej drugiego przęsła² (ryc. 1).

Grób nr 24/II (ryc. 2), zniszczony częściowo przez sąsiadujący z nim grobowiec nr 27 i położony nad nim grób nr 23, jest orientowany wzdłuż linii wschód-zachód ze śladami trumny, z której

\footnotetext{
${ }^{1}$ Ogólne sprawozdanie z badań w Kruszwicy, gdzie wyniki wykopalisk w kolegiacie obejmują zaledwie kilka zdań znajdujemy w pracy: A. Cofta-Broniewska, E. Springer, K. Tymieniecka, Wyniki prac terenowych w 1960 roku w Kruszwicy, pow. Inowrocław, „Sprawozdania Archeologiczne”, 14, 1962, s. 248-249. Jedynie znaleziona w czasie tych prac jedwabna stuła została opublikowana przez E. Springer w artykule: L'étole du haut Mouen Age trouvée à Kruszwica, „Archeologia Polona”, 6, 1964, s. 338-339 oraz wymieniona w dziele Sztuka polska przedromańska i romańska do schytku XIII wieku, red. M. Walicki, [cz. 2], Warszawa 1971, s. 724.

2 Opis grobów oparty jest na zachowanej z Archiwum Instytutu Archeologii i Etnologii PAN dokumentacji rysunkowej nieznanego autora, oraz maszynopisu Ewy Springer, Cmentarzysko szkieletowe na stan. 6 w Kruszwicy (w ramach tematu: Dokumentacja zespołu osadniczego w Kruszwicy w pradziejach i we wczesnym średniowieczu).
} 


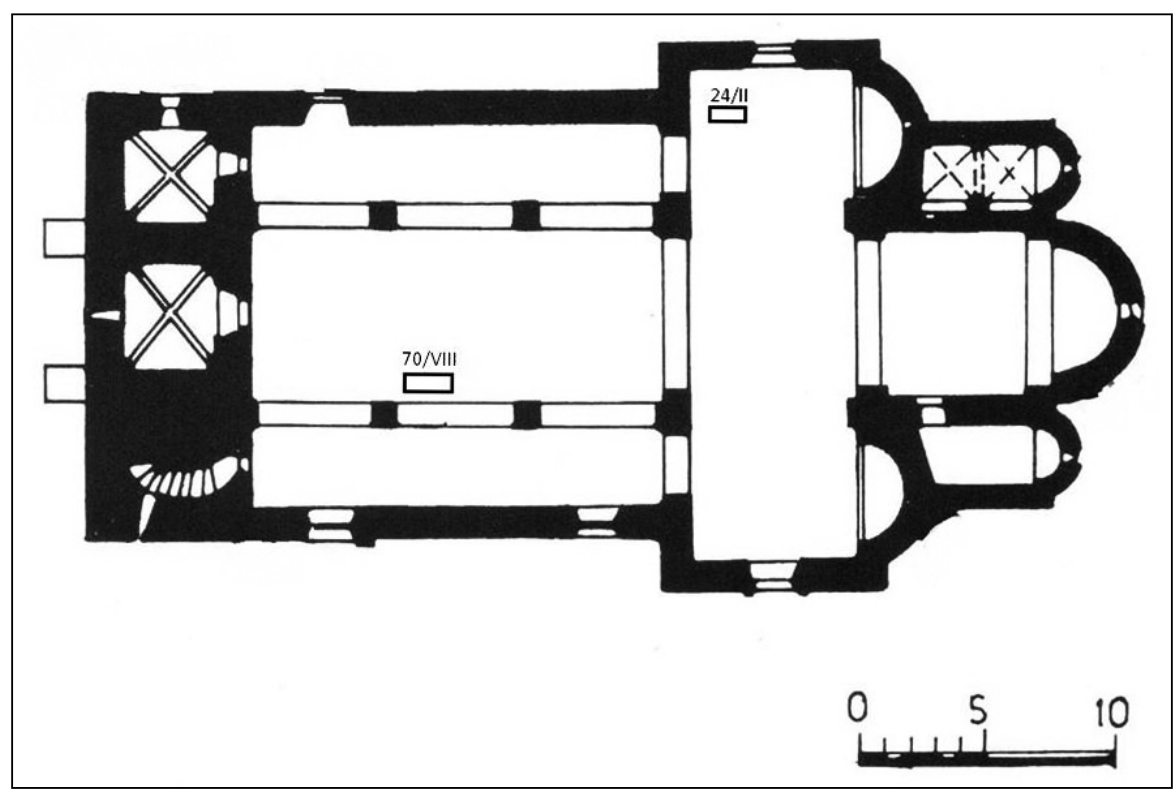

1. Kruszwica, kościół pw. św. św. Piotra i Pawła, plan z zaznaczeniem grobów osób duchownych. Archiwum IAE PAN

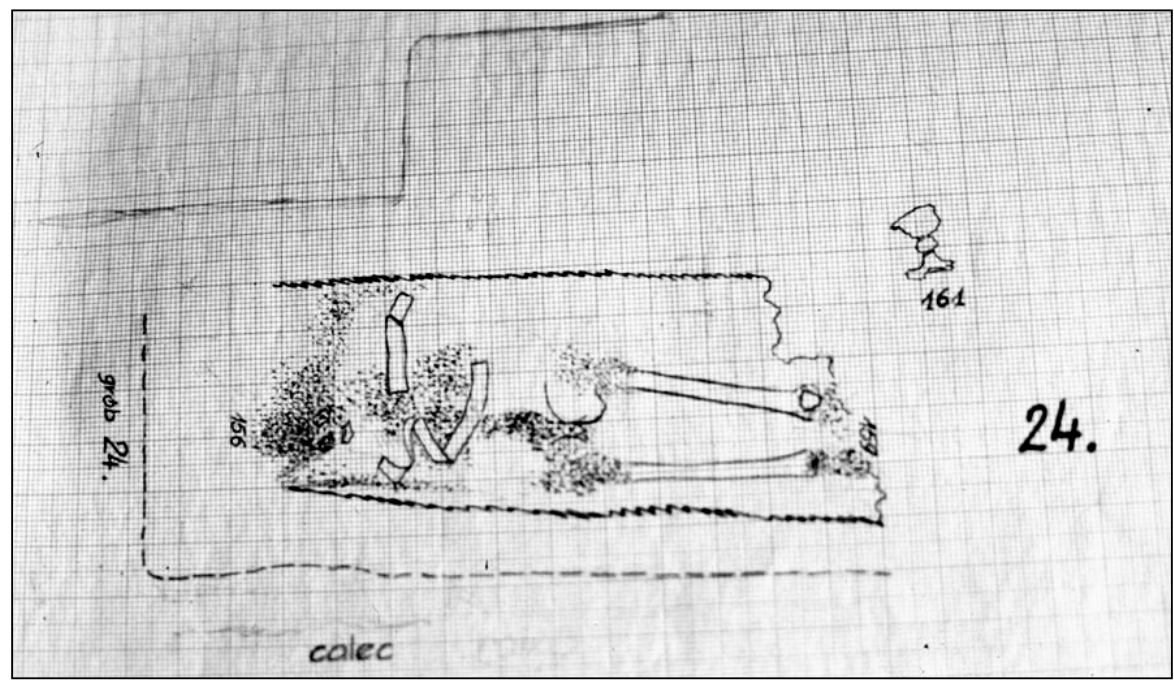

2. Kruszwica, kościół pw. św. św. Piotra i Pawła, plan grobu nr 24, skala 1:10. Archiwum IAE PAN

zachowało się jedynie dno i ściany boczne. Szkielet skierowany głową na zachód, z tym że dobrze zachowały się tylko kości długie nóg, brak zaś czaszki, a z kręgosłupa, żeber, kości ramion i miednicy pozostały tylko nikłe ślady. Na wysokości żeber szkieletu znaleziono resztki haftowanych taśm jedwabnych ${ }^{3}$. Brak jest natomiast kości stóp, wskutek przecięcia wschodniej partii grobu wkopem. Około 1 metra od grobu, lecz na jego osi, znaleziono pokruszony mały kielich srebrny wraz z pateną. Najprawdopodobniej zawartość grobu została poruszona i zapewne częściowo wyrabowana w czasie przygotowywania wkopu pod grób nr 23.

\footnotetext{
${ }_{3}^{3}$ M. Janicki, Romańskie napisy haftowane na jedwabnych pasmach z grobu nr 24 w kolegiacie w Kruszwicy, St. Źrodł., 54,
} 2016, s. 41. 


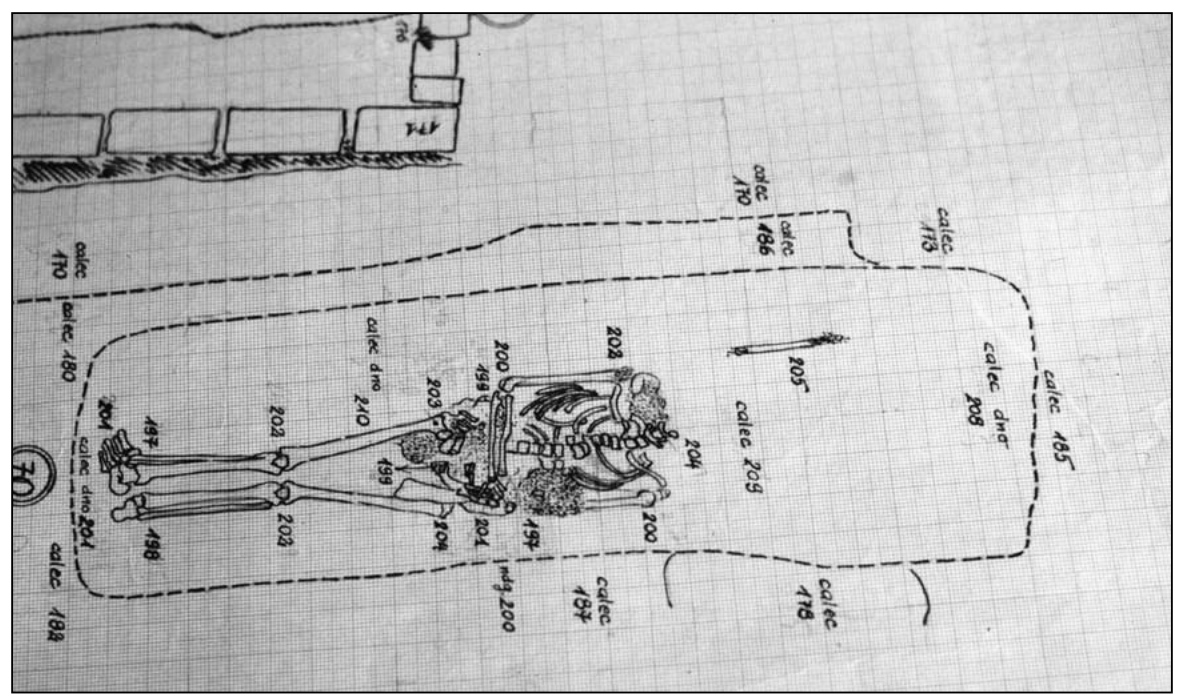

3. Kruszwica, kościół pw. św. św. Piotra i Pawła, plan grobu nr 70, skala 1:10. Archiwum IAE PAN

Kielich i patena wykonane ze srebra ze znacznym dodatkiem miedzi, zostały wydobyte z ziemi we fragmentach. Po dokonaniu konserwacji i częściowej rekonstrukcji kielich ma wysokość 9,2 cm, średnicę otworu kulistej czary, identyczną ze średnicą stopy kielicha, wynoszącą 7,2 cm i średnicę kulistego nodusu $-2,5 \mathrm{~cm}$. Patena miała kształt okrągły lub owalny o średnicy około $8,5 \mathrm{~cm}$. Brak jakiejkolwiek ornamentyki obydwu naczyń ${ }^{4}$ (ryc. 4).

Grób nr 70/VII (ryc. 3), orientowany wzdłuż linii wschód-zachód, zawierał w dużej prostokątnej trumnie o wymiarach $60 \times 210 \mathrm{~cm}$, prawie kompletny szkielet, brak jednak czaszki i kości długiej prawego przedramienia. Kość ta zdaje się być wyjęta z grobu i porzucona nieco na wschód od pochów$\mathrm{ku}$, co wskazywałoby na późniejsze otwarcie grobu. Zmarły ułożony był głową na zachód, z rękami skrzyżowanymi na miednicy. Na wysokości miednicy szkieletu znaleziono trzy fragmenty jedwabnej haftowanej stuły.

Pochówki te były roboczo datowane na wiek XII. Przeprowadzone ostatnio badania poszczególnych znajdowanych w grobach przedmiotów, w tym epigraficzne i tekstylioznawcze, starają się sie to datowanie uściślić. Nie należy jednak traktować tych obu zespołów grobowych, jako sobie współczesnych.

Srebrne przedmioty liturgiczne: kielich z pateną, pochodzące zapewne z grobu nr 24, stanowiły począwszy od VIII wieku, specyficzne elementy wyposażenia grobów osób duchownych. Zawierały one konsekrowane lub niekonsekrowane hostie i wino, będąc rodzajem wiatyku na ostatnią drogę zmarłego, a więc communio mortuorum. Zwyczaj ten był zwalczany przez Kościół prawie od początku jego istnienia, lecz przetrwał do wieków średnich, kiedy to w wieku XIII kielich i patena, stały się atrybutami kapłaństwa. Znajdujemy je zarówno w grobach szeregowych duchownych jak i biskupów i opatów 5 .

Znaleziony w Kruszwicy kielich wykonany jest ze srebra, co już w pewnym sensie podkreśla pozycję społeczną zmarłego. Niesłusznym jest określanie go jako kielicha grobowego, to jest sporządzonego wyłącznie dla złożenia do grobu. W znanych nam inwentarzach skarbców kościelnych występuje podział na kielichy duże calix maior i kielichy małe calix minor. Często też odnajdujemy

\footnotetext{
${ }^{4}$ Konserwacja i częściowa rekonstrukcja została wykonana przez Włodzimierza Pinskwara z Muzeum Początków Państwa Polskiego w Gnieźnie.

${ }^{5}$ E. Dąbrowska, Paszport do niebios - rozważania o mentalności ludzi średniowiecza, w: tejże, Groby, relikwie i insygnia. Studia z dziejów mentalności średniowiecznej, Warszawa 2008, s. 162-167.
} 


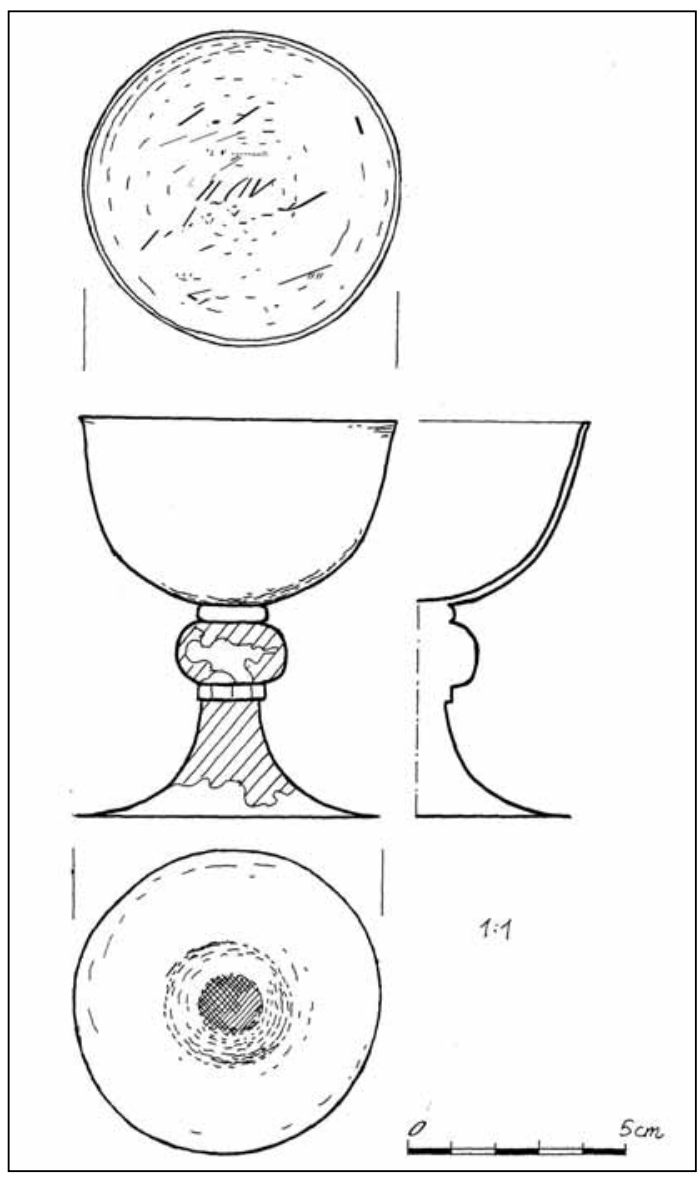

4. Kruszwica, kościół pw. św. św. Piotra i Pawła, srebrny kielich znaleziony obok grobu nr 24. Rys. Ł. Drzewiecka-Ranoszek

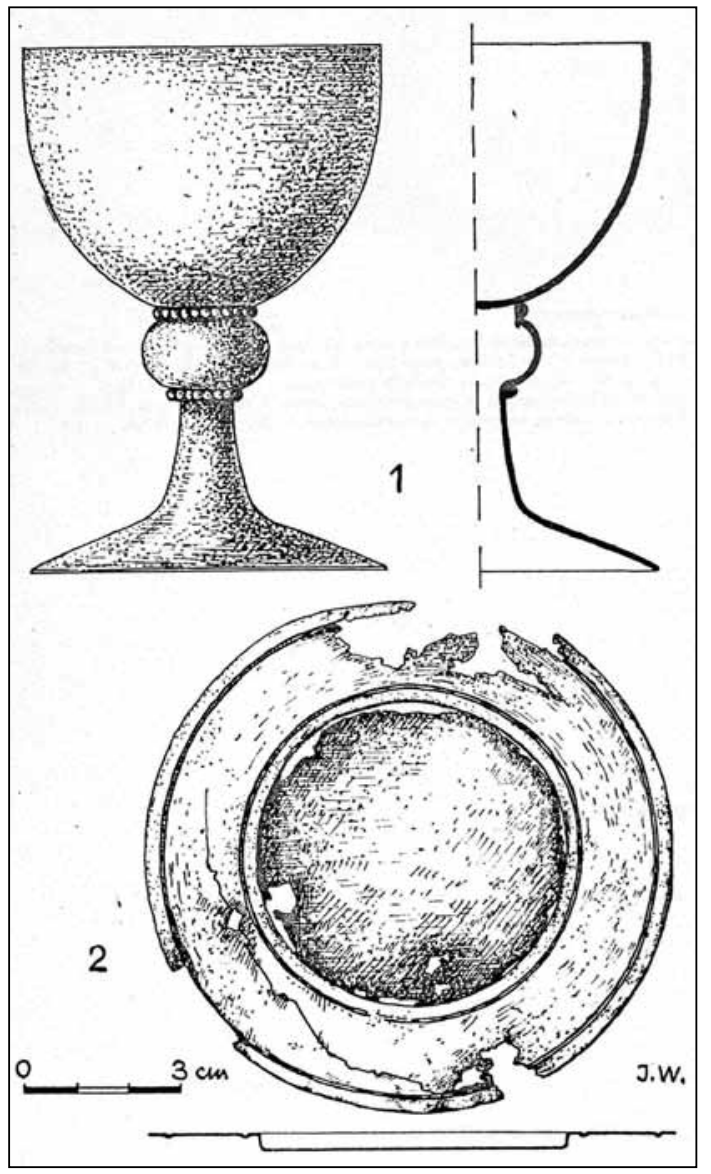

5. Tum pod Łęczycą, kościół pw. Wniebowzięcia NM. Panny, kielich i patena z grobu nr 1.

Wg A. Abramowicz, A. Nadolski,

T. Poklewski. Tombes d'ecclésiastiques, pl. 188(3)

w grobach kielichy bogato ornamentowane, jak na przykład srebrny kielich, znaleziony wraz z pateną w grobie krakowskiego biskupa Maura zmarkego w roku $1118^{6}$.

Kielich kruszwicki o prawie identycznych wymiarach średnicy czaszy i stopy, wykonany jest w proporcjach: średnica czaszy $=$ średnica stopy $=2 / 3$ wysokości kielicha $>$ średnica pateny. Forma ta jest dość rozpowszechniona w wiekach XI i XII (około 16 kielichów w obydwu zbiorach Wiktora Elberna ${ }^{7}$ ), przy czym najstarsze okazy charakteryzują się szczególnie małymi rozmiarami, ponieważ mają 4 lub $5 \mathrm{~cm}^{8}$ wysokości. Analogiczne co do formy kielichy większych rozmiarów odnoszone są do wieku XII. Wśród wyróżnionych 11 mamy jedynie 5 pochodzących ze zidentyfikowanych grobów, a to biskupa Monastyru (Münster) Fridricha I zmarłego w roku 10849, opata Reginharda z Siegburga

\footnotetext{
${ }^{6}$ A. Bochnak, Grób biskupa Maura w krypcie św. Leonarda na Wawelu, „Rocznik Krakowski”, 30, 1938, s. 239-248; E. M. Nosek, Konserwacja wczesnośredniowiecznego srebrnego kielicha i pateny z grobu biskupa Maura w katedrze na Wawelu, „Studia Waweliana”, 2, 1993, s. 31-40.

7 V. H. Elbern, Der eucharistische Kelch im frühen Mittelalter, „Zeitschrift des deutschen Vereins für Kunstwissenschaft”, 17, 1963, s. 33-75; tenże, Der eucharistische Kelch im frühen Mittelalter, neue Funde und Forschungen, „Arte Medievale”, 2. ser., 9 (1), 1995, s. 1-48.

${ }^{8}$ Są to kielichy znalezione w Trewirze w grobie arcybiskupa Poppo zmarłego w 1047 r. i w Brixen w grobie niezidentyfikowanego prałata, V. H. Elbern, Der eucharististiche Kelch..., nr 33, s. 75; tenże, Der eucharistische Kelch im frühen Mittelalter, neue Funde, nr 3, fig. 3, s. 12.

${ }^{9}$ V. H. Elbern, Der eucharistische Kelch im frühen Mittelalter, neue Funde, nr 26, fig. 26a, s. $27-29$.
} 
z 1105 r. ${ }^{10}$, wspomnianego już biskupa krakowskiego Maura z roku 1118 r. ${ }^{11}$, arcybiskupa Trewiru Albero von Montreuil zmarłego w roku $1152^{12}$ a w końcu Henryka Kietlicza arcybiskupa gnieźnieńskiego zmarkego w roku $1219^{13}$ (ryc. 5). Ta ostatnia data nie oznacza jednak, iż kielichy omawianej formy produkowano jeszcze w wieku XIII, gdyż bardzo często składano do grobu egzemplarze zniszczone lub niemodne. Ponadto kielichy o opisanej formie znaleziono $\mathrm{w}$ niezidentyfikowanych grobach biskupich i opackich z Bambergu, Osnabrück, Poznania (groby nr 93 i 157) i Spiry ${ }^{14}$.

Stwierdzić można, iż kielich kruszwicki został wykonany w pierwszej polowie wieku XII, nie wykluczając całkowicie i drugiej połowy tego wieku i że jest formalnie zbliżony do kielichów nadreńskich. Problem rodzimego pochodzenia naczyń liturgicznych badanego okresu wymaga odrębnej dyskusji.

Tkaniny jedwabne znalezione w grobach $\mathrm{nr} 24$ i nr 70 mogą być datowane tylko w ogólnych ramach od XI do XIII wieku ${ }^{15}$. Pewne ustalenia może natomiast przynieść haft samej stuły. W zachowanych fragmentach znajdujemy postacie duchownych z pastorałami. Wszyscy oni są prawie jednakowo odziani w szaty pontyfikalne to znaczy w mitrę, amikt, czyli chustę na szyi, albę, dalmatykę i ornat z manipularzem. Błogosławiące ręce łączy stula. Nogi przykrywają pończochy tzw. caligae, na stopach sandały (ryc. 6).

$\mathrm{Na}$ specjalna uwagę zasługuje mitra, której forma może pozwolić na datowanie całego haftu. Mitra wśród elementów stroju pontyfikalnego jest nabytkiem stosunkowo późnym i wchodzi w użycie dopiero na przełomie XI i XII w. W 1049 r. papież Leon IX przyznaje prawo noszenia romana mitra, to jest takiej, jaką noszą biskupi Rzymu, Eberhardowi arcybiskupowi trewirskiemu i jego następcom ${ }^{16}$.

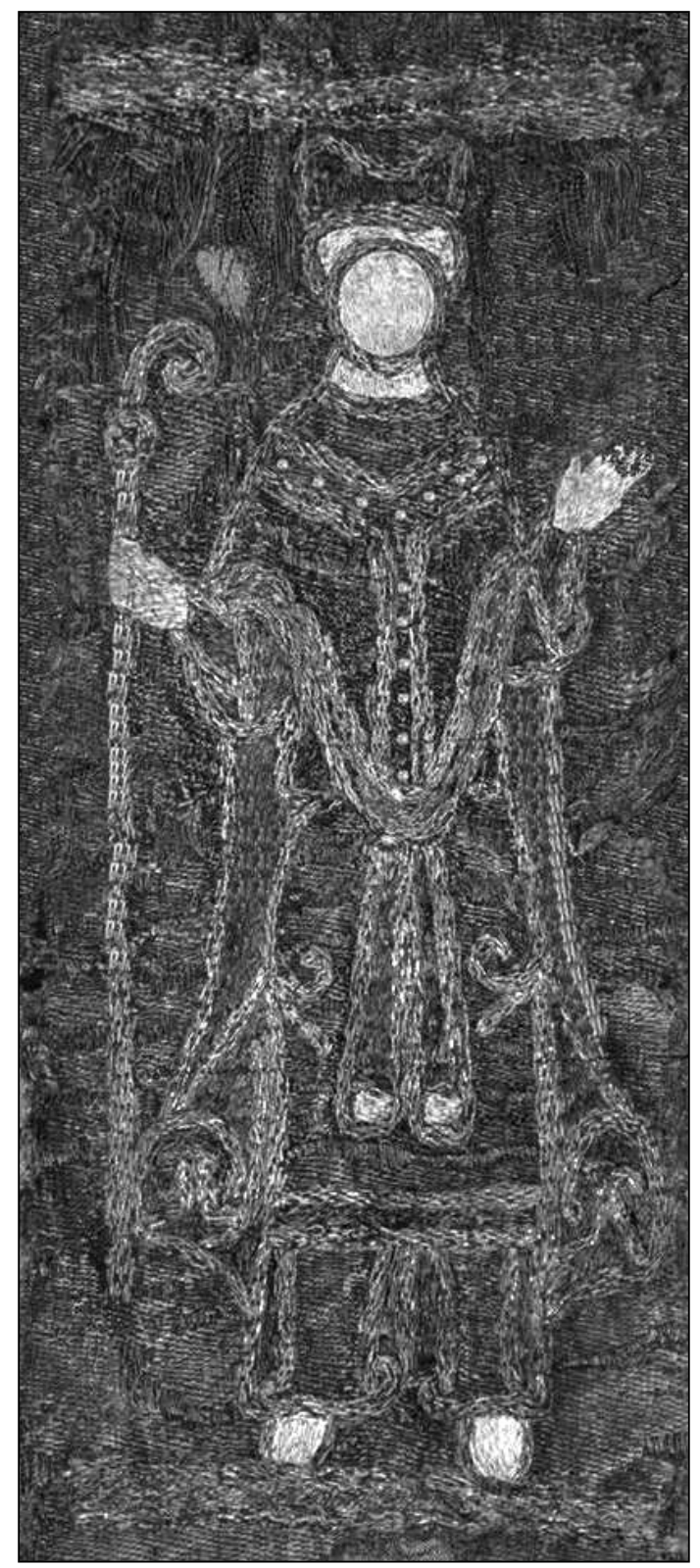

6. Kruszwica, kościół pw. św. św. Piotra i Pawła - fragment stuły z grobu nr 70. Fot. E. Mianowska

\footnotetext{
10 Tamże, nr 26, s. 75.

11 Zob. przypis 5.

12 „Zu ewigen Gedächtnis und Lob”. Die Grabstätten der Trierer Bischöfe in Dom und Liebfrauen, Trier 2004, s. 29.

13 A. Abramowicz, A. Nadolski, T. Poklewski, Tombes ecclésiastiques de Tum près de Łęczyca (XIIe-XIIIe siècle), „Inventaria Archaeologica” Pologne, 30, Łódź 1973, pl. 188(3); E. Dąbrowska, Krzyż arcybiskupów polskich, w: tejże, Groby, s. $57-71$.

${ }^{14}$ V. H. Elbern, Der eucharistische Kelch, nr 2, s. 67; V. H. Elbern, Der eucharistische Kelch im frühen Mittelalter, neue Funde, nr 29, 32, 33, 45, fig. 29, 32a, 33, s. 32-33, 35-36, 44.

${ }_{15}$ M. Cybulska, E. Orlińska-Mianowska, Fragmenty dwóch tkanin z depozytu Muzeum Narodowego w Warszawie znalezionych w kolegiacie w Kruszwicy w 1960 roku, St. Źrodł., 54, 2016, s. 31-39.

${ }_{16}$ Bulla papieża Leona IX dla arcybiskupstwa Trewiru — Ph. Jaffé, Regesta pontificum Romanorum, Lipsiae 1885, nr 4161, s. 531.
} 


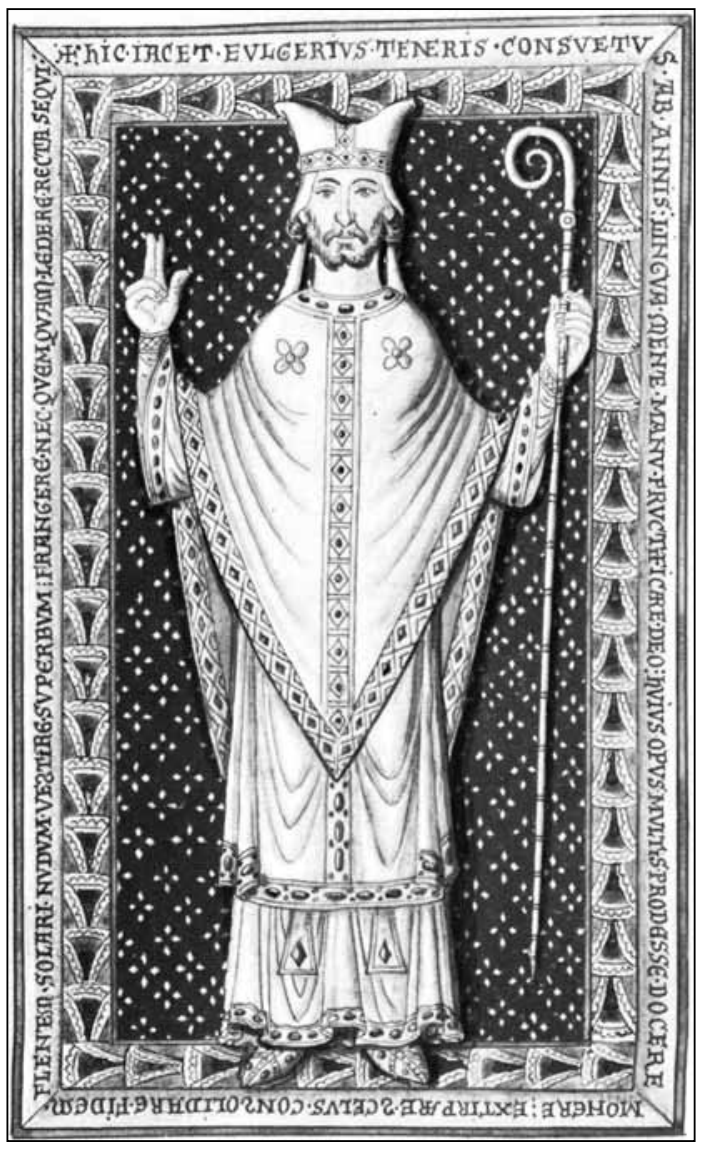

7. Płyta nagrobna Ulgera biskupa Angers, według rysunku R. Gaignieres, za M.-M. Gauthier,

G. François, Émaux Méridionaux, tabl. C,5

Przywilej ten otrzymali także od Leona IX kanonicy z Bambergu ${ }^{17}$, później zaś opaci wielkich opactw benedyktyńskich, takich jak: Canterbury w 1063 r., czy Cluny w 1088 r. W wieku XII mitra staje się powszechnym elementem stroju biskupiego, zaś niektórzy opaci otrzymują prawo jej noszenia na podstawie odrębnych przywilejów papieskich ${ }^{18}$.

Jeśli wierzyć schematowi przedstawionemu przez Józefa Brauna ${ }^{19}$, pierwotne mitry były spiczastymi lub półokrągłymi czapkami, z których wyodrębniły się dwie półkule, a w końcu dwa rogi. I to właśnie mitry dwurożne noszą biskupi wyobrażeni na stule kruszwickiej.

Niestety, według mojej znajomości przedmiotu, do naszych czasów nie zachowała się żadna mitra dwurożna. Znany je tylko z wyobrażeń na monetach, pieczęciach, grobowcach i miniaturach. Do najstarszych należy mitra Brunona von Bretten arcybiskupa Trewiru w latach 1102-1124, przedstawiona na jego monetach ${ }^{20}$, a także na monetach Arnolda arcybiskupa Trewiru w latach 1169-1183 ${ }^{21}$. Miniatury kroniki opactwa San Vicenzo al Volturno pochodzące z około roku 1108, przekazują liczne wyobrażenia tej mitry ${ }^{22}$.

Wkrótce po roku 1149 wykonany został emaliowany grobowiec Ulgera biskupa Angers ${ }^{23}$ (ryc. 7), a w drugiej połowie XII wieku mitry dwurożne występują już powszechnie tak na monetach jak i na pieczęciach $^{24}$, także i polskich — np. arcybiskupa gnieźnieńskiego Jana z roku 1153 (ryc. 8) ${ }^{25}$. Niemniej już od schyłku XII wieku mitry dwurożne zostają zastąpione przez mitry trójkątne, w pełni rozpowszechnione w wieku XIII ${ }^{26}$.

Zestawiając uzyskane poprzez badania przedmiotów liturgicznych i analizę epigraficzną wyhaftowanego napisu dane, wskazujące na wiek XII, możemy przypuścić, iż zabytki te zostały złożone do grobów w wieku XII. Należy jednak pamiętać, iż często składano do grobów przedmioty i szaty zużyte lub uszkodzone. Datowanie znalezionego w grobie przedmiotu, stanowi tylko terminus post quem samego pochówku. Niemniej w wypadku szat jedwabnych i kielicha wyko-

\footnotetext{
17 Anonymus Haserensis, De episcopis Eichstetensibus, wyd. L.C. Bethmann, MGH SS, t. 7, s. 264.

${ }_{18}$ P. Hofmeister, Mitra und Stab des wirklichen Prälaten ohne bischöflichen Charakter, „Kirchenrechtliche Abhandlungen”, 104, 1928, s. 58; P. Hofmeister, Das Ponticalprivileg more Abbatum, „Liturgisches Jahrbuch”, 1, 1951, s. 93-95.

19 J. Braun, Die liturgische Gewändung im Occident und Orient, Freiburg in Breisgau 1907, s. 475, ryc. 234.

${ }^{20}$ R. Weiller, Die Münzen von Trier, cz. 1, Düsseldorf 1988, nr 121, s. 411. Za odnalezienie tych wyobrażeń, składam profesorowi Stanisławowi Suchodolskiemu serdeczne podziękowania.

${ }^{21}$ R. Weiller, Die Münzen von Trier, nr 140, s. 435-436.

${ }^{22}$ B. Sirch, Der Ursprung der bischöflichen Mitra und päpstlichen Tiara, St. Ottilien 1975, s. 202, fig. 12.

${ }_{23}$ M.-M. Gauthier, G. François, Emaux méridionaux: catalogue international de l'œuvre de Limoges, t. 1, L'époque romane, Paris 1987, nr 106, s. 108, tabl. C,5.

${ }^{24}$ G. Demay, Le costume au moyen âge, d'après les sceaux, Paris 1880, s. 295-297.

${ }_{25}$ Sztuka polska przedromańska i romańska, s. 793.

${ }^{26}$ J. Braun, Die pontificalen Gewänder des Abendlandes nach ihrer geschichtlichen Entwicklung. Freiburg in Breisgau 1898, s. 36-50; M. Beaulieu, J. Baylé, La mitre épiscopale en France des origines à la fin du XVe siècle, «Bulletin archéologique du Comité des travaux historiques et scientifiques», nouvelle série, 9A, 1979, s. 44-50.
} 
nanego z marnego kruszcu, termin ten nie musiał być zbyt długi.

Bogate szaty haftowane złotymi nićmi, srebrny kielich, pochówki w trumnach wskazywałyby na wysoki status w hierarchii kościelnej pogrzebanych tam zmarłych. Nie należy zapominać, iż obydwa te groby zostały pozbawione części swego wyposażenia. Nie można więc wykluczyć, iż pierwotnie znajdowały się tam pierścienie i pastorały.

Dzieje kościoła pw. św. Piotra w Kruszwicy, a także samego biskupstwa kruszwickiego, wobec niewielkiej liczby zachowanych źródeł, o rozbieżnej, często enigmatycznej treści, są trudne do odtworzenia i mimo obfitej literatury, stanowią $\mathrm{w}$ dalszym ciągu przedmiot dyskusji ${ }^{27}$.

W roku 1133 bulla papieża Innocentego II skierowana do arcybiskupa magdeburskiego Norberta, podporząd-

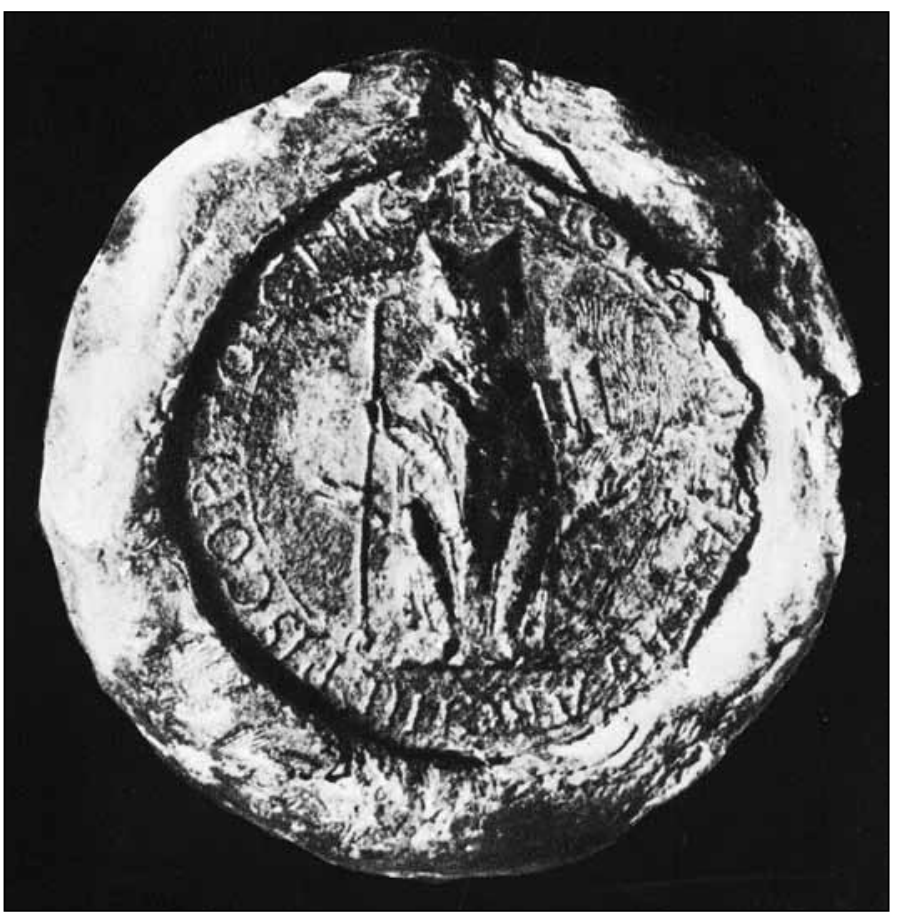

8. Pieczęć Jana arcybiskupa gnieźnieńskiego, według Sztuka polska przeromańska i romańska, s. 793 kowuje biskupstwo kruszwickie temu metropolicie $\mathrm{i}$ to jest pierwszy zapis stwierdzający istnienie tego biskupstwa ${ }^{28}$. Znamy też biskupów kruszwickich z XII wieku. Niejasnym jest natomiast czas założenia tego biskupstwa. W roku 1000 nie znajdujemy go bowiem wśród sufraganii arcybiskupstwa gnieźnieńskiego. Kronika wielkopolska przypisuje jego fundację Mieszkowi II ${ }^{29}$, którą, mimo późnego zapisu, Władysław Abraham skłonny jest uznać za wiarygodną. Podkreśla jednak, iż biskup kruszwicki nie występuje w przedmowie Kroniki Galla Anonima, więc do tego czasu biskupstwo nie zostało odnowione ${ }^{30}$. Natomiast Gerard Labuda wyklucza powstanie biskupstwa kruszwickiego w XI w. i jego fundację przypisuje działalności legata papieskiego Idziego w roku $1123^{31}$. Tę Władysław Abraham uważał za ponowną fundację tego biskupstwa ${ }^{32}$. Za rządów Bolesława Krzywoustego miało też powstać biskupstwo włocławskie ${ }^{33}$.

\footnotetext{
27 Wzmianka o „Crusviciensis monasterii Beati Apostoli” $w$ dokumencie księcia mazowieckiego Leszka z 1185 r. dla katedry włocławskiej (KDPol., t. 2, nr 2, s. 5), pozwoliła na wysunięcie tezy, najszerzej rozbudowanej przez Karola Górskiego, Topografia średniowiecznej Kruszwicy, „Studia Wczesnośredniowieczne”, 2, 1953, s. 50-53), powtórzonej przez W. Dzieduszyckiego, Kruszwica, w: Słownik starożytności słowiańskich, t. 8/2, s. 377-379 o istnieniu tam klasztoru benedyktyńskiego. Hipoteza ta nie została przyjęta przez Katarzynę Hewner, O datowaniu wczesnośredniowiecznej kolegiaty w Kruszwicy, Kwart. HKM, 44, 1996, z. 4, s. 431-436), pomimo wpływów z Hirsau w architekturze świątyni, zaś przez Marka Derwicha, Monastycyzm benedyktyński w średniowiecznej Europie i Polsce. Wybrane Problemy, Wrocław 1998, s. 190) została uznana za całkowite nieporozumienie.

${ }^{28}$ KDWlkp., t. 1, nr 6, s. 9; Ph. Jaffé, Regesta, nr 7629 (5458).

29 Kronika wielkopolska, wyd. B. Kürbis, MPH, t. 8, Warszawa 1970, § 11, s. 17.

${ }^{30}$ W. Abraham, Organizacja Kościoła w Polsce do połowy XII wieku, Poznań 1962, s. 145-146.

${ }^{31}$ G. Labuda, Początki diecezjalnej organizacji kościelnej na Pomorzu i na Kujawach w XI i XII wieku, Zap. Hist. 33, 1968, s. $39-41$.

32 W. Abraham, Organizacja Kościoła, s. 148.

33 G. Labuda, Początki diecezjalnej organizacji, s. 40-41.
} 
Podsumowując w $1996 \mathrm{r}$. dotychczasowe poglądy w historiografii na powstanie samodzielnej organizacji kościelnej na Kujawach, Maciej Michalski ${ }^{34}$, opowiedział się za fundacją w pierwszej połowie XII wieku na Kujawach dwóch biskupstw kruszwickiego i włocławskiego. Plany te nie zostały w pełni zrealizowane, czego wynikiem jest występowanie na Kujawach jednego tylko biskupstwa o bardzo zróżnicowanej

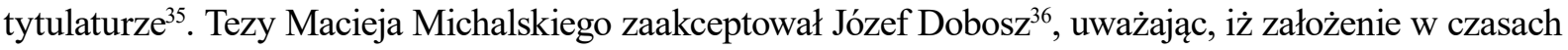
Bolesława Krzywoustego dwóch nowych diecezji (potwierdzonych bullą z $1133 \mathrm{r}^{37}$ ) nie przetrwało próby czasu i zapewne przed 4 kwietnia $1148^{38}$ doszło do połączenia dwóch małych biskupstw — kruszwickiego i włocławskiego - w jedno, z tytułem biskupstwa włocławskiego lub kujawskiego.

Na drugą ćwierć lub połowę XII w., datowane jest ukończenie obecnego kościoła kolegiackiego, ówczesnej katedry biskupiej ${ }^{39}$. Znani są też biskupi kruszwiccy tego czasu, Swidgerus zmarły przed rokiem 1148 i Onald (Honoldus), którego pontyfikat przypada na lata 1157-1160. Według Katalogu biskupów włocławskich (wolborskiego) w Kruszwicy mieli być pogrzebani poprzednicy Swidgera ${ }^{40}$. Powtarza to Jan Długosz, donosząc, że Swidigerus generis Almanici był pochowany w Kruszwicy ${ }^{41}$, zaś Onold (Honoldus) Italus już we Włocławku².

Brak podstaw, aby identyfikować zmarłych pochowanych w grobach $\mathrm{nr} 24$ i $70 \mathrm{w}$ kolegiacie w Kruszwicy. Niemniej, nie możemy wykluczyć, iż we wspomnianych grobach pogrzebani zostali biskupi kruszwiccy. Celem naszym jest zasygnalizowanie istnienia niecodziennych znalezisk w Kruszwicy i wprowadzenie wyhaftowanego tekstu z grobu nr 24 do zasobu epigrafiki polskiej.

\section{Unknown Tombs of Mediaeval Clergymen from the Collegiate Church of St. Peter and St. Paul in Kruszwica}

Summary: In 1960-1961 excavations were conducted in the interior of the collegiate church of St. Peter and St. Paul in Kruszwica as part of studies conducted by the Management for Research on the Beginnings of the Polish State. The research was supervised by Ewa Springer, M.A. Among 326 tombs explored in the interior of the building two, containing coffins, were opened but, unfortunately, had been previously tampered with and partly raided. One of the tombs (no. 24/II) contained a silver chalice with a paten and fragments of silk tape with an embroidered inscription, while the other (no. 70/VII) - an embroidered stole. The form of the chalice and the paten, the shape of the letters of the embroidered inscription, and the embroidery on the stole showing clergymen carrying two-horned mitres make it possible to date the Kruszwica monuments as twelfth-century. Their presence in tombs located in the Kruszwica collegiate church would indicate the high status within the Church hierarchy of the men buried there. Regrettably, both tombs were robbed of part of their outfitting and thus it is impossible to exclude that originally they also contained pastorals and rings.

In view of the scarcity of the preserved sources with diverse and enigmatic contents it is difficult to recreate the history of the church of St. Peter in Kruszwica as well as that of the Kruszwica bishopric. Undoubtedly, in the first half of the twelfth century Kruszwica was the seat of bishops and the church of St. Peter was the burial site of the local prelates.

\footnotetext{
${ }_{34}$ M. Michalski, Ustanowienie i wczesne dzieje biskupstwa kujawskiego, w: Scripta Minora, red. B. Lapis, t. 1, 1996, s. 83-108. Tam też pełne przedstawienie całości dyskusji, zreferowanej tutaj w znacznym skrócie.

${ }_{35}$ M. Michalski, Ustanowienie, s. 106-108.

${ }^{36}$ J. Dobosz, Monarchia i możni wobec Kościoła w Polsce do początków XIII wieku, Poznań 2002, s. 216-220.

${ }^{37}$ Zob. przypis 28.

${ }^{38}$ Bulla papieża Eugeniusza III dla Wernera biskupa włocławskiego, KDPol., t. 2, nr 1, s. 1; Ph. Jaffé, Regesta, nr 9222 (6410).

${ }^{39}$ K. Hewner, O datowaniu, s. 431-436; Z. Świechowski, Architektura romańska w Polsce, Warszawa 2000, s. 142-144; M. Wiewióra, Kolegiata w Kruszwicy świetle najnowszych badań, w: Osadnictwo i architektura ziem polskich w dobie zjazdu gnieźnieńskiego, red. A. Buko, Z. Świechowski, Warszawa 2000, s. 101-108.

${ }^{40}$ Catalogus episcoporum Wladislaviensium (Volboriensis), MPH, t. 4, s. 25; D. Karczeski, Swidger + przed 1148, w: PSB, t. 46, Kraków 2009, s. 129 n.

${ }^{41}$ Joannis Dlugossii, Catalogus episcoporum Wladislaviensium, w: tegoż: Opera omnia, t. 1, wyd. I. Polkowski, Ż. Pauli, Cracoviae 1887, s. 523.

42 Tamże, s. 524.
} 
Nota o autorze: E l ż b i e t a D ą b r o w s k a, profesor archeologii, wieloletni pracownik Instytutu Historii Kultury Materialnej (później Instytut Archelolgii i Etnologii) Polskiej Akademii Nauk.

Author: Elżbiet a Dąbrowska, archeologist, a longtime profesor at the Institute of History of Material Culture (later the Institute of Archaeology and Ethnology) of the Polish Academy of Sciences.

\section{Bibliografia}

Abraham W., Organizacja Kościoła w Polsce do połowy XII wieku, Poznań 1962

Beaulieu M., Baylé J., La mitre épiscopale en France des origines à la fin du XVe siècle, «Bulletin archéologique du Comité des travaux historiques et scientifiques», nouvelle série, 9A, 1979, s. 41-97

Braun J., Die pontificale Gewänder des Abendlandes nach ihrer geschichtlichen Entwicklung, Freiburg in Breisgau 1898

Braun J., Die liturgische Gewändung im Occident und Orient, Freiburg in Breisgau 1907

Dąbrowska E., Paszport do niebios - rozważania o mentalności ludzi średniowiecza, w: tejże, Groby, relikwie i insygnia. Studia z dziejów mentalności średniowiecznej, Warszawa 2008, s. 161-183

Demay G., Le costume au moyen âge, d'après les sceaux, Paris 1880

Dobosz J., Monarchia i możni wobec Kościoła w Polsce do poczatków XIII wieku, Poznań 2002

Elbern V. H., Der eucharististiche Kelch im frühen Mittelalter, „Zeitschrift für des deutsches Vereins für Kunstwissenschaft", 17, 1963, s. 33-75

Elbern V. H., Der eucharististiche Kelch im frühen Mittelalter, neue Funde und Forschungen, „Arte Medievale”, 1, 1995, s. $1-48$

Hewne K. r, O datowaniu wczesnośredniowiecznej kolegiaty w Kruszwicy, Kwart. HKM, 44, 1996, z. 4, s. 431436

Hofmeister P., Mitra und Stab des wirklichen Prälaten ohne bischöflichen Charakter, „Kirchenrechtliche Abhandlungen", 104, 1928, s. 1-131

Labuda G., Poczatki diecezjalnej organizacji kościelnej na Pomorzu i na Kujawach w XI i XII wieku, „Zap. Hist." 33, 1968, s. 19-59

Michalski M., Ustanowienie i wczesne dzieje biskupstwa kujawskiego, „Scripta minora”, red. B. Lapis, t. 1, 1996, s. 83-108

Sirch B., Der Ursprung der bischöflichen Mitra und päpstlichen Tiara, St. Ottilien 1975

Springer E., L'étole du haut Mouen Age trouvée à Kruszwica, „Archeologia Polona”, 6, 1964, s. 338-339

Świechowski Z., Architektura romańska w Polsce, Warszawa 2000

Weiller R., Die Münzen von Trier, teil 1, Düsseldorf 1988

„Zu ewigen Gedächtnis und Lob”. Die Grabstätten der Trierer Bischöfe in Dom und Liebfrauen, Trier 2004 